\title{
Streptosporangium terrae sp. nov., a novel actinomycete isolated from the rhizosphere of Callistemon citrinus (Curtis), India
}

\author{
Radha Vaddavalli ${ }^{1,2}$, Bagyanarayana Gaddam ${ }^{1,3}$ and Venkateswar Rao Linga ${ }^{4}$
}

A novel actinomycete strain, designated VRC2 $1^{\top}$, was isolated from the rhizosphere of Callistemon citrinus collected from Hyderabad, India. The morphological and chemotaxonomic properties of strain VRC21 ${ }^{\top}$ was consistent with the characteristics of members of the genus Streptosporangium, that is, the formation of sporangia on aerial mycelium, coiled unbranched hyphae within the spore vesicle, the presence of meso-diaminopimelic acid in the cell wall, and madurose and galactose as major whole-cell sugars. Diagnostic polar lipids were phosphatidylethanolamine, diphosphatidylglycerol, phosphatidylglycerol, phosphatidylinositol and phosphatidylinositol-mannosides. The predominant menaquinones were MK-9(H2) and MK-9(H4). The major cellular fatty acids were iso- $\mathrm{C}_{14: 0}$, iso- $\mathrm{C}_{16: 0}, \mathrm{C}_{17: 0}$ 10-methyl, $\mathrm{C}_{18: 1 \mathrm{w} 9 \mathrm{c}}$ and $\mathrm{C}_{18: 0}$ 10-methyl. 16S rRNA gene sequence analyses revealed that strain VRC2 $1^{\top}$ was a member of the genus Streptosporangium. The highest similarity values were observed with S. carneum DSM $44125^{\top}(98.2 \%)$ and S. fragile DSM $43847^{\top}(98.2 \%)$; the values of the remaining type strains were below $98 \%$. The values of DNA-DNA relatedness between the strain VRC21 ${ }^{\top}$ and the type strains of the related species were below $70 \%$. On the basis of the polyphasic evidence, the strain VRC21 ${ }^{\top}$ should be classified as novel species Streptosporangium terrae sp. nov. in the genus Streptosporangium. The type strain is VRC21 ${ }^{\top}\left(=\right.$ KCTC $29207^{\top}=$ MTCC $^{\circ}$ $11724^{\mathrm{T}}$ ).

The Journal of Antibiotics (2015) 68, 425-430; doi:10.1038/ja.2015.5; published online 18 February 2015

\section{INTRODUCTION}

The genus Streptosporangium was first described by Couch. ${ }^{1}$ The genus encompasses aerobic, Gram-stain-positive, non-acid-fast organisms with stable, unbranched, non-fragmenting substrate mycelium that carries cottony aerial mycelium, which differentiates into sporangiophores; spores are spherical, rod or oval shape and the sporangial walls are thick; organism has meso-diaminopimelic acid and madurose in the peptidoglycan; MK- $9\left(\mathrm{H}_{2}, \mathrm{H}_{4}\right)$ as predominant menaquinones; complex mixtures of iso-, anteiso-, saturated, unsaturated and 10-methyl branched fatty acids; phospatidylethanolamine, diphosphatidylglycerol, phosphatidylglycerol, phosphatidylinositol and glucosamine-containing polar lipids as major components; and has a DNA base composition within the range $69-71 \mathrm{~mol} \%$ GC. ${ }^{1}$ At the time of manuscript preparation, there were 17 species and 2 subspecies with validly published names (http://www.bacterio. net/streptosporangium.html): Streptosporangium roseum, ${ }^{1}$ S. amethystogenes, S. album, S. vulgare, S. amethystogenes, subsp. amethystogenes, ${ }^{2}$ and subsp. fukuiens, ${ }^{3}$ S. longisporum, ${ }^{4}$ S. nondiastaticum, S. pseudovulgare, ${ }^{5}$ S. violaceochromogenes, ${ }^{6}$ S. fragile, ${ }^{7}$ S. carneum, ${ }^{8}$ S. subroseum, ${ }^{9}$ S. purpuratum, S. yunnanense, ${ }^{10}$ S. canum, $^{11}$ S. oxazolinicum, ${ }^{12}$ S. anatoliense ${ }^{13}$ and S. sandarakinum. ${ }^{14}$
During our research work entitled 'Discovery of novel antimicrobial agents against Streptococcus pneumonia-A multidisciplinary approach', strain VRC $21^{\mathrm{T}}$ was isolated from rhizosphere of Callistemon citrinus, with the prospect that it might produce novel antimicrobial agents. Although our investigation was multidisciplinary, the main aim was to discover novel antimicrobial agents against Streptococcus pneumonia. To achieve the goal, we have isolated few active compounds (under the process of publication) from C. citrinus leaves solvent extracts. Another major source for novel antimicrobial agents is soil microbes. In this regard, soil was collected from C. citrinus plant rhizosphere, because $C$. citrinus roots produce leptospermone. Leptospermone is the blue print of the compound mesotrione that has been proven to be an effective herbicide. ${ }^{15}$ C. citrinus being rich in terpenoids, produces many essential oils, which give good fragrance that surrounds the plant, including its rhizosphere soil. This plant grows widely as an ornamental plant in India, having potential medicinal properties that were proved not only by literature but also by our previous research work. This formed the basis in selecting the plant rhizosphere for actinomycetes isolation, identification, characterization and screening for secondary metabolites. The present study was carried out to determine the taxonomic status of the strain VRC $21^{\mathrm{T}}$ by using a polyphasic approach.

${ }^{1}$ Department of Botany, Osmania University, Hyderabad, Telangana State, India; ${ }^{2}$ School of Chemistry, University of Hyderabad, Hyderabad, Telangana State, India; ${ }^{3}$ Department of Botany, Palamuru University, Palamuru, Telangana State, India and ${ }^{4}$ Department of Microbiology, Osmania University, Hyderabad, Telangana State, India Correspondence: Professor L VenkateswarRao, Department of Microbiology, University College of Science, Osmania University, Hyderabad 500007, India. E-mail: vrlinga@gmail.com

Received 19 January 2014; revised 29 December 2014; accepted 12 January 2015; published online 18 February 2015 


\section{MATERIALS AND METHODS}

Strain VRC21 ${ }^{\mathrm{T}}$ was isolated from the rhizosphere of C. citrinus (Curtis) Skeels, from Hyderabad, India (GPS coordinates for the sampling site is $17^{\circ} 23^{\prime} 6.7374^{\prime \prime}$ $\left.\mathrm{N} 78^{\circ} 29^{\prime} 11.979^{\prime \prime} \mathrm{E}\right)$. Soil samples were collected in sterile tubes and brought to the laboratory of Osmania University, India. Samples were dried in laminar flow under aseptic conditions. Samples were serially diluted with sterilized distilled water, and up to $10^{-5}$ dilutions were made; $0.1 \mathrm{ml}$ suspension from each dilution was spread on yeast extract malt extract agar (ISP medium 2) $)^{16}$ plates. The plates were observed intermittently during incubation. Pinpoint colonies with a clear zone of inhibition and the dominant reddish pink color colony were selected and maintained on ISP medium 2 at $4{ }^{\circ} \mathrm{C}$ and in glycerol suspensions $(20 \% \mathrm{v} / \mathrm{v})$ at $-20^{\circ} \mathrm{C}$.

The strain VRC21 ${ }^{\mathrm{T}}$, S. fragile DSM $43847^{\mathrm{T}}$ and S. carneum DSM $44125^{\mathrm{T}}$ were cultured for 3 weeks at $30^{\circ} \mathrm{C}$ and the cultural characteristics were observed on ISP (International Streptomyces Project) media 2, 3, 4, 5, 6 and 7, ${ }^{16}$ starch casein agar and nutrient agar. ${ }^{17}$ For morphological characterization, 21-day-old cultures on ISP medium 2 were taken. The cover slip technique ${ }^{18}$ was used to observe hyphae and spore chains by light microscopy (Olympus microscope BH-2, Delhi, India). Spore texture, spore-chain morphology and spore ornamentation were studied by scanning electron micrography. Specimens were prepared according to Williams and Davies, ${ }^{19}$ and stub was prepared according to our previous study. ${ }^{20}$ Finally, the sample was sputtered with gold (E-1010, Ion sputter with Gold, Model S-3700N, Hitachi, Japan). The color of substrate, aerial mycelia and soluble pigments were determined by comparison with chips from the ISCC-NBS color charts. ${ }^{21} \mathrm{~A}$ range of physiological tests such as growth at different temperatures $\left(4,10,15,20,25,30,35,40\right.$ and $45^{\circ}$ C), $\mathrm{pH}$ values (4.0-11.0) and $\mathrm{NaCl}$ concentrations (3, 5, 7 and 9\% (w/v)) were examined on ISP medium $2 .{ }^{18}$ Assimilation of various carbohydrates as the sole carbon source was tested using ISP medium $9 .{ }^{22}$ Biochemical characteristics, $\mathrm{H}_{2} \mathrm{~S}$ production and sensitivity of the strain to different antibiotics ${ }^{23}$ were

Table 1 Cultural characteristics of strain VRC2 $1^{\top}$ and closely related type strains

\begin{tabular}{|c|c|c|c|}
\hline Medium & $V R C 21^{T}$ & S. carneum DSM $44125^{T}$ & S. fragile DSM $43847^{T}$ \\
\hline \multicolumn{4}{|l|}{ ISP medium 2} \\
\hline \multirow[t]{2}{*}{ Growth } & Good & Good & Good \\
\hline & Very dark red (RC) & Sunrise yellow (10C7) & Chocolate brown (4pn) \\
\hline Reverse & Very dark red (RC) & Brown $(\mathrm{S})$ & Brown (S) \\
\hline Aerial mycelium & Pale pink g $(7 \mathrm{ca})$ & White (a) & White (a) \\
\hline Soluble pigment & Deep purple wine g (11 pl) & None & None \\
\hline \multicolumn{4}{|l|}{ ISP medium 3} \\
\hline \multirow[t]{2}{*}{ Growth } & Good & Good & Good \\
\hline & Very dark red (RC) & Sunrise yellow (10C7) & Brown (S) \\
\hline Reverse & Very dark red (RC) & Brown $(\mathrm{S})$ & Brown (S) \\
\hline Aerial mycelium & $\begin{array}{l}\text { Poor, white (a) to } \\
\text { Pale pink g (7ca) }\end{array}$ & White (a) & White (a) \\
\hline Soluble pigment & Deep purple wine g (11 pl) & None & None \\
\hline \multicolumn{4}{|l|}{ ISP medium 4} \\
\hline \multirow[t]{2}{*}{ Growth } & Good & Good & Good \\
\hline & Dark reddish brown (RC) & Pale pink (7ca) & Chestnut brown (S) \\
\hline Reverse & $\begin{array}{l}\text { Very dark rose }(8 \mathrm{lc}) \\
\text { dark rose }(8 \mathrm{Ic})\end{array}$ & Yellow brown (S) & Chestnut brown (S) \\
\hline Aerial mycelium & Pale pink g (7ca) to & Pale pink g (7ca) & White (a) \\
\hline Soluble pigment & Dark rose brown (7 pn) & None & None \\
\hline \multicolumn{4}{|l|}{ ISP medium 5} \\
\hline \multirow{2}{*}{ Growth } & Good & Good & Good \\
\hline & Dark reddish brown (RC) & Orange yellow (S) & Orange (S) \\
\hline Reverse & Very dark red $(\mathrm{RC})$ & Orange (S) & Orange brown (S) \\
\hline Aerial mycelium & $\begin{array}{l}\text { Poor, white (a) to } \\
\text { Pale pink g (7ca) }\end{array}$ & Pale pink g (7ca) & White (a) \\
\hline Soluble pigment & Deep purple wine g (11 pl) & None & None \\
\hline \multicolumn{4}{|l|}{ ISP medium 6} \\
\hline \multirow[t]{2}{*}{ Growth } & Good & Good & Good \\
\hline & Very dark red (RC) & Orange (S) & Chestnut brown (S) \\
\hline Reverse & Very dark red (RC) & Orange (S) & Yellow brown (S) \\
\hline Aerial mycelium & Pale pink g (7ca) & Pale pink g (7ca) & White (a) \\
\hline Soluble pigment & Deep purple wine g (11 pl) & Light Reddish brown (SC) & None \\
\hline \multicolumn{4}{|l|}{ ISP medium 7} \\
\hline \multirow[t]{2}{*}{ Growth } & Good & Good & Good \\
\hline & Dark reddish brown (RC) & Orange (S) & Orange (S) \\
\hline Reverse & Very dark red (RC) & Orange (S) & Chestnut brown (S) \\
\hline Aerial mycelium & Pale pink g (7ca) & Pale pink g (7ca) & White (a) \\
\hline Soluble pigment & Deep purple wine g (11 pl) & None & None \\
\hline \multicolumn{4}{|l|}{ Starch casein agar } \\
\hline \multirow[t]{2}{*}{ Growth } & Sparse & Good & Good \\
\hline & $\begin{array}{l}\text { Pale pink ( } 7 \mathrm{ca}) \text { to dark } \\
\text { Rose brown ( } 7 \mathrm{pn})\end{array}$ & Orange (S) & Orange (S) \\
\hline Reverse & $\begin{array}{l}\text { Pale pink }(7 \mathrm{ca}) \text { to } \\
\text { Dark rose brown }(7 \mathrm{pn})\end{array}$ & Yellow (S) & Chestnut brown (S) \\
\hline Aerial mycelium & Pale pink $(7 \mathrm{ca})$ & None & White (a) \\
\hline Soluble pigment & Light rose (7 1/2 ga) & None & None \\
\hline \multicolumn{4}{|l|}{ Nutrient agar } \\
\hline \multirow[t]{2}{*}{ Growth } & Sparse & Good & Good \\
\hline & Pale pink (7 ca) & Orange (S) & Orange (S) \\
\hline Reverse & Pale pink (7 ca) & Yellow (S) & Orange brown (S) \\
\hline Aerial mycelium & Poor, white (a) & None & White (a) \\
\hline Soluble pigment & Light wine (7 1/2 ne) & None & None \\
\hline
\end{tabular}

Color designation based on Color Universal Language and Dictionary of Names. ${ }^{20}$ 
determined using the methods of Korn-Wendisch et al. ${ }^{24}$ Starch hydrolysis was examined using ISP medium 4, and for nitrate reduction ISP medium 8 was used. ${ }^{16}$ Tyrosinase activity was determined using ISP medium $7 .^{25}$ Enzyme activities were determined using the API ZYM system (bioMerieux, Lyon, France) according to the manufacturer's instructions. Biomass for molecular and chemotaxonomic studies was obtained after incubation in shake flasks of trypticase soy broth medium (Hi-Media, Mumbai, India) at $30^{\circ} \mathrm{C}$ for 7 days with rotary aeration (180 r.p.m.). The isomer type of diaminopimelic acid in cell wall peptidoglycan was determined by the method of Hasegawa et al. ${ }^{26}$ Whole-cell sugars were studied as described by Staneck and Roberts. ${ }^{27}$ Cellular fatty acid analysis was determined by the method of Sasser, ${ }^{28}$ using MIDI Sherlock version 6.0, MIDI database RTSBA6. Polar lipids were extracted and analyzed according to the method of Minnikin et al., ${ }^{29}$ and Komagata and Suzuki. ${ }^{30}$ Mycolic acids were tested by the acid methanolysis method of Minnikin et al. ${ }^{31}$ Menaquinones were extracted and examined by using the method of Collins et al. ${ }^{32}$ and analyzed by HPLC..$^{33}$ The $N$-acyl types of muramic acid were determined by the method of Uchida and Aida. ${ }^{34}$ Isolation of $\mathrm{DNA}^{35}$ and determination of DNA G+C content was carried out according to the method of Marmur and Doty. ${ }^{36}$ The levels of DNA-DNA relatedness was performed by using dot-blot hybridization method of Chung et al. ${ }^{37}$ and a simple fluorimetric method for estimation of DNA-DNA relatedness based on thermal denaturation temperatures. ${ }^{38}$ The $16 \mathrm{~S}$ rRNA was amplified using the bacterial universal primers and sequencing was performed under contract by Macrogen Inc. (Kumchun-Ku, Seoul, South Korea) using a 3730XL DNA analyzer (Applied Biosystems, Seoul, South Korea). The 16S rRNA gene sequence was aligned with related sequences belonging to the genus Streptosporangium by using CLUSTAL W. ${ }^{39}$ Pairwise evolutionary distances were calculated using the DNADIST program with the Kimura two parameter model as developed by Kimura. ${ }^{40}$ Multiple sequence alignments with most closely related Streptosporangium species similarity were carried out using EzTaxon-e server (http://eztaxon-e.ezbiocloud.net/). ${ }^{41}$ Phylogenetic tree analysis was performed using MEGA6. ${ }^{42}$ The phylogenetic tree was constructed based on the neighbor-joining, ${ }^{43}$ maximum-parsimony ${ }^{44}$ and maximum-likelihood ${ }^{45}$ algorithms. Data were resampled 1000 bootstrap replications. ${ }^{46}$

\section{RESULTS AND DISCUSSION}

\section{Morphological, cultural and physiological characteristics}

The cultural characteristics of strain VRC $21^{\mathrm{T}}$, along with those of the type strains of the closely related species, S. fragile DSM $43847^{\mathrm{T}}$ and S. carneum DSM $44125^{\mathrm{T}}$, are given in Table 1 . Strain $\mathrm{VRC} 21^{\mathrm{T}}$ grew well and formed extensively branched and non-fragmented substrate mycelia on various tested agar media. The colony color of strain VRC $21^{\mathrm{T}}$ was dark reddish brown with a dark reddish brown color soluble pigment when grown on various media (Table 1). The temperature and $\mathrm{pH}$ range for growth were $10-35^{\circ} \mathrm{C}$ and $\mathrm{pH} 7-9$, respectively, with optimum growth occurring at $30^{\circ} \mathrm{C}$ and $\mathrm{pH} 7$. Strain $\mathrm{VRC} 21^{\mathrm{T}}$ tolerated up to $3 \% \mathrm{NaCl}(\mathrm{w} / \mathrm{v})$ and exhibited good growth on ISP 2, ISP 3, ISP 4, ISP 5, ISP 6 and ISP 7, sparse growth on nutrient agar and starch casein agar, and no growth on Czapek's agar and potato dextrose agar. It produced pink colored aerial mycelia and very dark reddish brown colored substrate mycelia, and its spores were spherical, non-motile and present within sporangia; abundant sporangia formed from the aerial hyphae (Figure 1), and a very dark reddish brown diffusible pigment was observed. Casein was degraded. Starch was hydrolyzed. Gelatin was liquefied, milk was peptonized and coagulated. Nitrate was not reduced to nitrite and $\mathrm{H}_{2} \mathrm{~S}$ gas was not produced. Melanin was produced. The Voges Proskauer's reactions and methyl red tests were positive. The results of other physiological and biochemical analyses are summarized in the species description and Table 2 below.

\section{Chemotaxonomic characteristics}

Cell-wall peptidoglycan of strain VRC $21^{\mathrm{T}}$ contained meso-diaminopimelic acid as the diagnostic diamino acid. Whole-cell sugars were madurose, galactose, glucose, xylose and arabinose. The acyl type of muramic acid was $\mathrm{N}$-acetyl. Mycolic acids were not found. The major cellular fatty acids were (\%): iso- $\mathrm{C}_{14: 0}(9.07), \mathrm{C}_{14: 0}$ (5.06), iso- $\mathrm{C}_{16: 1}$

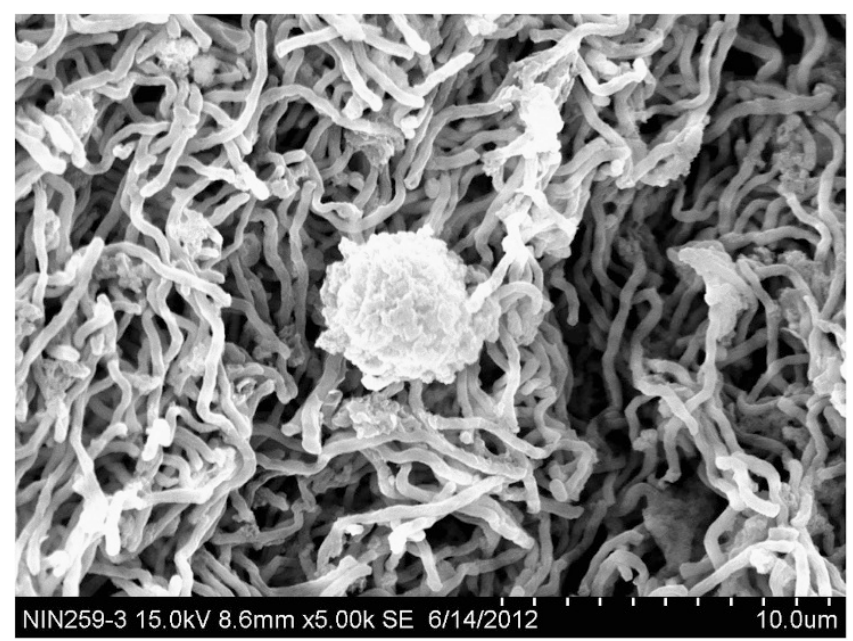

Figure 1 Scanning electron micrograph of strain VRC21 $1^{\top}$ grown on ISP 2 medium for 21 days at $30^{\circ} \mathrm{C}$. Bar, 10 um.

Table 2 Comparison of physiological characteristics of strain VRC21 ${ }^{\top}$ and closely related type strains of related species

\begin{tabular}{|c|c|c|c|}
\hline Characterstics & $V R C 21^{T}$ & $\begin{array}{c}\text { S. carneum DSM } \\
44125^{T}\end{array}$ & $\begin{array}{c}\text { S. fragile DSM } \\
43847^{T}\end{array}$ \\
\hline \multicolumn{4}{|l|}{ Degradation of: } \\
\hline Adenine & - & - & + \\
\hline Casein & + & + & - \\
\hline Chitin & - & + & - \\
\hline Elastin & - & - & - \\
\hline Starch & + & - & + \\
\hline Urea & + & - & + \\
\hline Tyrosine & - & + & + \\
\hline Xanthine & + & - & - \\
\hline Hypoxanthine & + & - & + \\
\hline Reduction of nitrate & - & - & + \\
\hline $\mathrm{NaCl}$ tolerance $(\%, \mathrm{w} / \mathrm{v})$ & $0-3$ & $0-2$ & $0-2$ \\
\hline Temperature range $\left({ }^{\circ} \mathrm{C}\right)$ & 10-35 & 20-37 & $15-45$ \\
\hline \multicolumn{4}{|l|}{ Growth on sole carbon: } \\
\hline L-Arabinose & + & - & - \\
\hline D-Galactose & + & + & - \\
\hline D-Lactose & + & + & - \\
\hline D-Maltose & + & - & - \\
\hline D-Raffinose & + & - & - \\
\hline L-Rhamnose & + & - & - \\
\hline D-Sucrose & + & - & - \\
\hline D-Xylose & + & - & - \\
\hline \multicolumn{4}{|l|}{ Enzyme activity of } \\
\hline Esterase $\left(\mathrm{C}_{4}\right)$ & + & w & - \\
\hline Esterase lipase $\left(\mathrm{C}_{8}\right)$ & - & - & + \\
\hline Valine allylamidase & w & - & w \\
\hline Trypsin & - & + & + \\
\hline$\alpha$-Chymotrypsin & + & - & - \\
\hline Acid phosaphatase & - & w & + \\
\hline $\begin{array}{l}\text { Napthol-AS-BI- } \\
\text { phosphohydrase }\end{array}$ & - & + & w \\
\hline$\beta$-Galactosidase & + & + & - \\
\hline$\beta$-Glucuronidase+ & - & w & \\
\hline$\alpha$-Glucosidase & + & - & - \\
\hline$\beta$-Glucosidase & + & - & + \\
\hline$N$-acetyl- $\beta$-glucosaminidase & + & w & - \\
\hline$\alpha$-Mannosidase & + & - & + \\
\hline
\end{tabular}

Abbreviations: - , negative; +, positive; w, weakly positive. All the data are from this study. 
(11.80), C $16: 0$ (14.11), C-17:0 10-methyl (5.98), C $18: 1 \mathrm{w} 9 \mathrm{c}$ (4.26), $\mathrm{C}_{18: 0}$ 10-methyl, TBSA (8.16). (Table 3). The predominant menaquinones were MK-9 $\left(\mathrm{H}_{2}\right)(52 \%)$ and MK-9 $\left(\mathrm{H}_{4}\right)(44 \%)$, and MK-9( $\left.\mathrm{H}_{6}\right)(4 \%)$ was

Table 3 Cellular fatty acid compositions (\%) of strain VRC21 ${ }^{\top}$ and type strains

\begin{tabular}{|c|c|c|c|}
\hline Fatty Acid & $V R C 21^{T}$ & S. carneum & S. fragile \\
\hline $13: 0$ & 0.66 & 1.21 & 3.21 \\
\hline $14: 0$ iso & 9.07 & 3.45 & 7.45 \\
\hline 14:0 & 5.06 & 6.86 & 3.75 \\
\hline 15:0 & 1.20 & 2.28 & 1.31 \\
\hline $15: 0$ iso & 1.41 & 0.65 & 1.24 \\
\hline 15:0 anteiso & 0.94 & 1.32 & 1.33 \\
\hline $16: 1$ iso $\mathrm{G}$ & 2.11 & ND & 1.45 \\
\hline $16: 1$ cis 9 & 2.41 & 1.36 & 3.01 \\
\hline $16: 1$ iso & 11.80 & 3.44 & 10.9 \\
\hline 16:0 10 methyl & 3.1 & 2.87 & 3.03 \\
\hline 16:0 & 14.11 & 18.21 & 16.1 \\
\hline $17: 0$ cis 9 & 3.58 & 4.90 & 6.24 \\
\hline 17:0 anteiso & 0.50 & ND & 0.64 \\
\hline $17: 1$ w8c & 2.49 & 0.94 & 1.11 \\
\hline $17: 1$ iso $\mathrm{G}$ & 4.32 & 19.41 & 2.54 \\
\hline $17: 0$ & 1.19 & 1.63 & 4.54 \\
\hline 17:0 10-methyl & 5.98 & 4.21 & 3.02 \\
\hline $18: 1$ iso $\mathrm{F}$ & ND & 6.93 & 2.01 \\
\hline $18: 1$ cis 9 & ND & 4.89 & 14.0 \\
\hline $18: 1 w 9 c$ & 4.26 & 1.64 & 2.13 \\
\hline $18: 0$ & 1.80 & 1.11 & 5.40 \\
\hline 18:1 w7c 11-methyl & 0.63 & 2.47 & ND \\
\hline $17: 02 \mathrm{OH}$ & 0.74 & 1.22 & 2.12 \\
\hline 18:0 10-methyl, TBSA & 8.16 & ND & 3.45 \\
\hline Summed feature $3^{a}$ & 8.59 & ND & 2.32 \\
\hline Summed feature $9^{a}$ & 3.51 & 1.54 & ND \\
\hline
\end{tabular}

All the data are from this study. Values are percentages of total fatty acids; fatty acids amounting to $<0.50 \%$ in all species are not shown; ND, not detected.

Summed features 3,9 contains $16: 1$ w7c and/or $16: 1$ w6c, 16:0 10-methyl and/or 17:1 iso w9c, respectively.

asummed features are groups of two or three fatty acids that cannot be separated by GC with the MIDI system. detected as a minor component. Strain VRC $21^{\mathrm{T}}$ contained phosphatidylethanolamine, diphosphatidylglycerol, phosphatidylglycerol, phosphatidylinositol, two phosphatidylinositol-mannosides, one unidentified glycolipid, two unidentified phosphoaminolipids, three unidentified phospholipids and nine unidentified lipids. The DNA $\mathrm{G}+\mathrm{C}$ content was $69.5 \pm 1.5 \mathrm{~mol} \%$.

\section{Phylogenetic analysis}

The 16S rRNA gene sequence (1466 bp) of strain VRC21 $1^{\mathrm{T}}$ showed a close relationship with members of the genus Streptosporangium, and the similarity values between strain $\mathrm{VRC} 21^{\mathrm{T}}$ and the type strains in the genus Streptosporangium were 96.7-98.2\%. Although strain VRC $21^{\mathrm{T}}$ showed the highest similarity values to S. carneum DSM $44125^{\mathrm{T}}$ (98.2\%) and S. fragile DSM $43847^{\mathrm{T}}(98.2 \%)$, the strain did not form a reliable cluster with any members of the genus Streptosporangium (Figure 2). The Genbank accession number of the 16S rRNA gene sequences of strain VRC $21^{\mathrm{T}}$ is JX082289.

Table 4 DNA-DNA relatedness between strain $\operatorname{VRC} 21^{\top}$ and closely related type strains

\begin{tabular}{|c|c|c|c|}
\hline \multirow[b]{2}{*}{ Strain } & \multicolumn{3}{|c|}{ DNA-DNA relatedness with labeled strains (\%) a } \\
\hline & 1 & 2 & 3 \\
\hline 1 & 100 & 34 & 30 \\
\hline 2 & 33 & 100 & 40 \\
\hline 3 & 28 & 43 & 100 \\
\hline
\end{tabular}

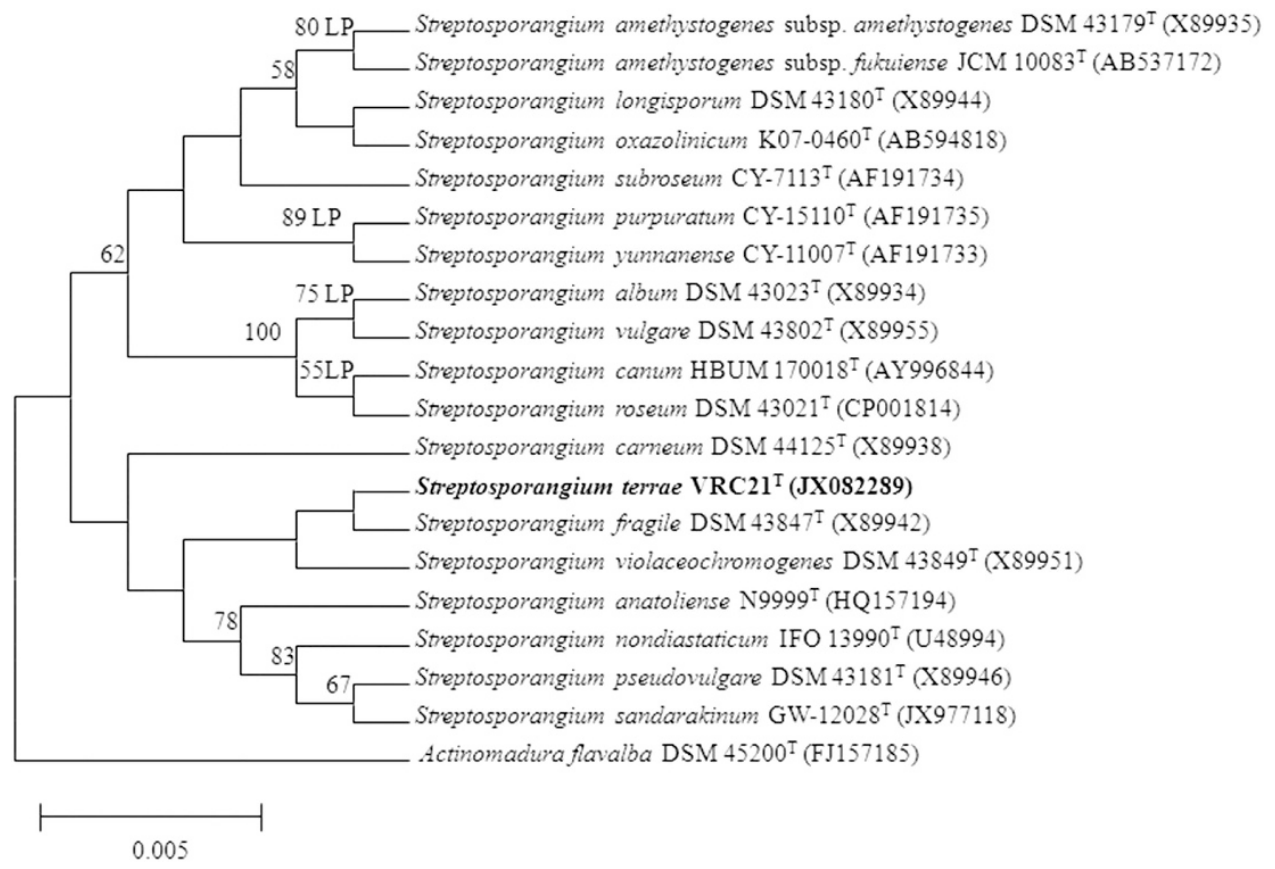

Figure 2 Neighbor-joining (NJ) phylogenetic dendrogram, based on 16S rRNA gene sequence analysis showing the position of strain VRC21 ${ }^{\top}$ within the genus Streptosporangium. Only bootstrap values above 50\% (percentages of 1000 replications) are indicated. Actinomadura flavalba DSM $45200^{\top}$ (FJ157185) was taken as an out group. L, branch also recovered in the maximum-likelihood tree; $\mathrm{P}$, branch also recovered in the maimum-parsimony tree. Bar 0.005 nucleotide substitutions per position. 


\section{DNA-DNA hybridization}

The DNA-DNA relatedness values among strain VRC21 ${ }^{\mathrm{T}}$, S. carneum DSM $44125^{\mathrm{T}}$ and $S$. fragile DSM $43847^{\mathrm{T}}$ were in the range of $28-43 \%$ (Table 4). These values were below the value of $70 \%$ that was recommended by Wayne et al. ${ }^{47}$ for the assignment of strains to the same species, and these results thus confirm that strain VRC $21^{\mathrm{T}}$ distinct from their closely related phylogenetic neighbors.

\section{CONCLUSION}

The phylogenetic analysis and morphological and chemotaxonomic properties indicated that the strain $\mathrm{VRC} 21^{\mathrm{T}}$ belongs to the genus Streptosporangium. However, DNA-DNA relatedness values between strain $\mathrm{VRC} 21^{\mathrm{T}}$ and the closely related type strains were below $70 \%$ (Table 4). Furthermore, colonies of strain VRC $21^{\mathrm{T}}$ could also be distinguished from its closest relatives by additional phenotypic characteristics. In strain $\mathrm{VRC} 21^{\mathrm{T}}$, the spore shape was spherical, whereas in S. carneum DSM $44125^{\mathrm{T}}$ and S. fragile DSM $43847^{\mathrm{T}}$, spores were in oval shaped. Strain VRC $21^{\mathrm{T}}$ produced very dark reddish brown colored substrate mycelium, whereas $S$. carneum DSM $44125^{\mathrm{T}}$ produced orange to yellow brown colored and S. fragile DSM $43847^{\mathrm{T}}$ produced dark brown to black colored substrate mycelium. S. carneum DSM $44125^{\mathrm{T}}$ did not produce a soluble pigment and $S$. fragile DSM $43847^{\mathrm{T}}$ produced a brown colored diffusible pigment, but strain VRC $21^{\mathrm{T}}$ produced a very dark reddish brown colored pigment. A comparison of the cultural and physiological characteristics and fatty acid composition of strain VRC $21^{\mathrm{T}}$ with its closest relatives of the genus Streptosporangium is given in Tables 1, 2 and 3.

Furthermore, as shown in Tables 1 and 2, many differences among strain VRC21 ${ }^{\mathrm{T}}$, S. carneum DSM $44125^{\mathrm{T}}$ and S. fragile DSM $43847^{\mathrm{T}}$ were observed. On the basis of the data presented in this study, we suggest that $\mathrm{VRC} 21^{\mathrm{T}}$ represents a novel species of the genus Streptosporangium, for which the name Streptosporangium terrae sp. nov. is proposed.

\section{Description of Streptosporangium terrae sp. nov.}

Streptosporangium terrae (ter'rae. L. gen. n. terrae of the earth).

It is a aerobic, Gram-positive, non motile actinomycete with extensive, non-fragmented dark reddish brown colored substrate mycelium. The sporangia contains spherical shape smooth spores. Colony appears leathery and cottony with aerial mycelium, sporangial walls are thick, and abundant big sporangiophores with spherical and non-motile spores are present. A very dark reddish brown colored diffusible pigment is observed. Colony size is $2-4 \mathrm{~mm}$. The temperature and $\mathrm{pH}$ range for growth were $10-35^{\circ} \mathrm{C}$ and $\mathrm{pH} 7-9$, with

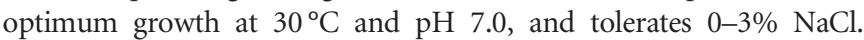
Siderophore activity is not seen. Growth is not found in the presence of inhibitory compounds such as crystal violet $(0.05 \% \mathrm{w} / \mathrm{v})$, phenol $(1.5 \% \mathrm{w} / \mathrm{v})$, sodium azide $(0.001 \% \mathrm{w} / \mathrm{v})$, lysozyme $(0.005 \% \mathrm{w} / \mathrm{v})$, potassium tellurite $(0.005 \%$ and $0.01 \% \mathrm{w} / \mathrm{v})$. Acid is produced from lactose, inositol, sorbitol, mannitol and maltose. No acid is produced from arabinose, xylose, adonitol, rhamnose and glucose. It gives a positive result in tests of catalase, oxidase and urease activities. Positive results were observed for gelatin liquefaction, milk coagulation, peptonization and starch hydrolysis. Tweens 40, 80 and aesculin are not hydrolysed. It is able to degrade casein, starch, urea, xanthine and hypoxanthine. It does not degrade adenine, chitin, elastin and tyrosine. Nitrate is not reduced to nitrite and $\mathrm{H}_{2} \mathrm{~S}$ gas is not produced. Enzyme activities of the API ZYM system are positive for esterase (C4), valine allylamidase, $\alpha$-chymotrypsin, $\beta$-galactosidase, $\beta$-glucuronidase, $\alpha$ glucosidase, $\beta$-glucosidase, $N$-acetyl- $\beta$-glucosaminidase and $\alpha$-mannosidase, weakly positive for esterase lipase $\left(\mathrm{C}_{8}\right)$ and negative for trypsin, acid phosaphatase, napthol-AS-BI-phosphohydrase. The Voges Proskauer's reactions and methyl red are positive; lysine, ornithine, citrate and malonate utilization, phenylalanine deamination, and indole, inulin, sodium gluconate, glycerol, salicin, dulcitol, arbitol, erythritol and alpha-methyl-D-glucoside are positive. It produces melanoid pigments. It utilizes a variety of organic compounds as sole carbon sources, including inulin, arabinose, dextrin, dextrose, fructose, glycerol, galactose, mannose, maltose, starch, xylose, raffinose, rhamnose, lactose and sucrose. But sodium gluconate, cellobiose, melibiose, saccharose and trehalose are not utilized. It utilizes arginine, asparagine, histidine, methionine, proline and tyrosin. It is resistant to ofloxacin $\left(1 \mu \mathrm{gl}^{-1}\right)$, penicillin $\mathrm{G}\left(1 \mu \mathrm{gl}^{-1}\right)$, cephalothin $\left(1 \mu \mathrm{gl}^{-1}\right)$, gentamycin $\left(1 \mu \mathrm{gl}^{-1}\right)$ and vancomycin $\left(1 \mu \mathrm{gl}^{-1}\right)$, but susceptible to co-trimoxazole $\left(1 \mu \mathrm{gl}^{-1}\right)$, clindamycin $\left(1 \mu \mathrm{gl}^{-} 1\right)$, erythromycin $\left(1 \mu \mathrm{gl} 1^{-1}\right)$, kanamycin $\left(25 \mu \mathrm{gl}^{-1}\right)$ and amphicillin $\left(10 \mu \mathrm{g} \mathrm{l^{-1 }}\right)$. The major cellular fatty acids are iso- $\mathrm{C}_{16: 1}, \mathrm{C}_{16: 0}$ and $\mathrm{C}_{18: 0}$ 10-methyl, TBSA. Cell wall peptidoglycan contains meso-diaminopimelic acid. Wholecell sugars are madurose, galactose, glucose, xylose and arabinose. Major diagnostic polar lipids are phosphatidylethanolamine, diphosphatidylglycerol, phosphatidylglycerol, phosphatidylinositol and two phosphatidylinositol-mannosides. The predominant menaquinones are MK-9 $\left(\mathrm{H}_{2}\right)$ and MK-9 $\left(\mathrm{H}_{4}\right)$. The $\mathrm{G}+\mathrm{C}$ content of the genomic DNA of the type strain is $69.5 \pm 1.5 \mathrm{~mol} \%$. Inhibitory activity is showed against Staphylococcus aureus (MTCC 7443). The type strain, VRC $21^{\mathrm{T}}\left(=\right.$ KCTC $29207^{\mathrm{T}}=$ MTCC $\left.11724^{\mathrm{T}}\right)$, was isolated from the rhizosphere of Callistemon citrinus collected from Hyderabad, India.

\section{ACKNOWLEDGEMENTS}

We are grateful to Dr Ch. Mohan Rao, Director (Center for Cellular and Molecular Biology, Hyderabad) for providing facilities to do key experiments, Dr R.B.N. Prasad, Head, Lipid Science \& Technology (Indian Institute of Chemical Technology, Hyderabad) for providing facilities for chemotaxonomic studies. We thank Professor Jean Paul Marie Euzeby for his help with the nomenclature. We are thankful to Dr K. Suresh, Scientist, and Mr Pradeep Kumar Singh (Institute of Microbial Technology, Chandigarh) for helping in phospholipid analysis.

1 Couch, J. N. A new genus and family of the Actinomycetales, with a revision of the genus Actinoplanes. J. Elisha Mitchell Sci. Soc. 71, 148-155 (1955)

2 Nonomura, H. \& Ohara, Y. Distribution of the actinomycetes in soil. V. The isolation and classification of the genus Streptosporangium. J. Ferment. Technol. 38, 405-409 (1960).

3 linuma, S., Yokota, A. \& Kanamura, T. New subspecies of the genus Streptosporangium, Streptosporangium amethystogenes subsp. fukuiense subsp. nov. Actinomycetologica 10, 35-42 (1996).

4 Schafer, D. Eine neue. Streptosporangium-Art aus turkischer Steppenerde. Arch. Mikrobiol. 66, 365-373 (in German) (1969).

5 Nonomura, H. \& Ohara, Y. Distribution of the actinomycetes in soil. VII. A culture method effective for both preferential isolation and enumeration of Microbispora and Streptosporangium strains in soil. Part 2. Classification of the isolates. J. Ferment. Technol. 47, 701-709 (1969).

6 Kawamoto, I. et al. A new antibiotic victomycin (XK 49-1-B-2). I. Taxonomy and production of the producing organism. J. Antibiot. (Tokyo) 28, 358-365 (1975).

7 Shearer, M. C., Colman, P. M. \& Nash, C. H. III Streptosporangium fragile sp. nov. Int. J. Syst. Bacteriol. 33, 364-368 (1983).

8 Mertz, F. P. \& Yao, R. C. Streptosporangium carneum sp. nov. isolated from soil. Int. J. Syst. Bacteriol. 40, 247-253 (1990).

9 Zhang, L., Jiang, C. \& Chen, W. Streptosporangium subroseum sp. nov., an actinomycete with an unusual phospholipid pattern. Int. J. Syst. Evol. Microbiol. 52, 1235-1238 (2002).

10 Zhang, L. P., Jiang, C. L. \& Chen, W. X. Streptosporangium yunnanense sp. nov. and Streptosporangium purpuratum sp. nov., from soil in China. Int. J. Syst. Evol. Microbiol. 55, 719-724 (2005).

11 Zhang, L. P., Zhang, L.M. \& Zhang, X. M. Streptosporangium canum sp. nov., isolated from soil. Int. J. Syst. Evol. Microbiol. 59, 1715-1719 (2009). 
12 Inahashi, Y., Matsumoto, A., Omura, S. \& Takahashi, Y. Streptosporangium oxazolinicum sp. nov., a novel endophytic actinomycete producing new antitrypanosomal antibiotics, spoxazomicins. J. Antibiot. 64, 297-302 (2011).

13 Anil, S. et al. Streptosporangium anatoliense sp. nov., isolated from soil in Turkey. Antonie Van Leeuwenhoek 102, 269-276 (2012).

14 Kämpfer, P., Glaeser, S. P., Grun-Wollny, I. \& Busse, H. J. Streptosporangium sandarakinum sp. nov. Int. J. Syst. Evol. Microbiol. 63, 2484-2489 (2013).

15 Derek, C. Callisto: a very successful maize herbicide inspired by allelochemistry. Fourth World Congress on Alleopathy. (2005) (http://www.regional.org.au/au/allelopathy/ 2005/2/7/2636_cornesd.htm).

16 Shirling, E. B. \& Gottlieb, D. Methods for characterization of Streptomyces species. Int J. Syst. Bacteriol. 16, 313-340 (1966).

17 Waksman S. A. (ed.) in: The Actinomycetes Vol. 2 (Williams and wilkins Co.: Baltimore, 1961).

18 Zhou, Z. H., Liu, Z. H., Qian, Y. D., Kim, S. B. \& Goodfellow, M. Saccharopolyspora spinosporotrichia sp. nov., a novel actinomycete from soil. Int. J. Syst. Bacteriol. $\mathbf{4 8}$ 53-58 (1998).

19 Williams, S. T. \& Davies, F. L. Use of scanning electron microscope for the examination of actinomycetes. J. Gen. Microbiol. 48, 171-177 (1967).

20 Vaddavalli R. et al. Saccharopolyspora indica sp. nov., an actinomycete isolated from the rhizosphere of Callistemon citrinus (Curtis). Int. J. Syst. Evol. Microbiol. 64 1559-1565 (2014)

21 Kelly, K. L. Inter-Society Color Council-National Bureau of Standards Color Name Charts IIlustrated with Centroid Colors, US Government Printing Office: Washington, DC, (1964).

22 Pridham, T. G. \& Gottlieb, D. The utilization of carbon compounds by some Actinomycetales as an aid for species determination. J. Bacteriol. 56, 107-114 (1948).

23 Radha, V., Sneha, P., Srilekha., Y. K. \& Venkateswar, R. L. Nocardia bhagyanesis sp. nov., a novel actinomycete isolated from the rhizosphere of Callistemon citrinus (Curtis), India. Antonie Van Leeuwenhoek 105, 443-450 (2014).

24 Korn-Wendisch, F., Kempf, A., Grund, E., Kroppenstedt, R. M. \& Kutzner, H. J. Transfer of Faenia rectivirgula Kurup and Agre 1983 to the genus Saccharopolyspora Lacey and Goodfellow 1975, elevation of Saccharopolyspora hirsute subsp. taberi Labeda 1987 to species level, and emended description of the genus Saccharopolyspora. Int. J. Syst. Bacteriol. 39, 430-441 (1989).

25 Dastager S. G. et al. Seperation, identification and analysis of pigment (melanin) production in Streptomyces. Afr. J. Bio. 8, 1131-1134 (2006)

26 Hasegawa, T., Takizawa, M. \& Tanida, S. A rapid analysis for chemical grouping of aerobic actinomycetes. J. Gen. Appl. Microbiol. 29, 319-322 (1983).

27 Staneck, J. L. \& Roberts, G. D. Simplified approach to identification of aerobic actinomycetes by thin layer chromatography. Appl. Microbiol. 28, 226-231 (1974).

28 Sasser, M. Identification of bacteria by gas chromatography of cellular fatty acids, MIDI Technical Note 101 (MIDI Inc: Newyark, DE, 1990).
29 Minnikin D. E. et al. An integrated procedure for the extraction of bacterial isoprenoid quinines and polar lipids. J. Microbiol. Methods 2, 233-241 (1984)

30 Komagata, K. \& Suzuki, K. Lipids and cell-wall analysis inbacterial systematics. Methods Microbiol. 19, 161-203 (1987).

31 Minnikin, D. E., Hutchinson, I. G., Caldicott, A. B. \& Goodfellow, M. Thinlayer chromatography of methanolysates of mycolic acid containing bacteria. J. Chromatogr. 188, 221-233 (1980)

32 Collins, M. D., Pirouz, T., Goodfellow, M. \& Minnikin, D. E. Distribution of menaquinones in actinomycetes and corynebacteria. J. Gen. Microbiol. 100, 221-230 (1977).

33 Groth, I. et al. Demetria terragena gen. nov., sp. nov., a new genus of actinomycetes isolated from compost soil. Int. J. Syst. Bacteriol. 47, 1129-1133 (1997).

34 Uchida, K. \& Aida, K. Acyl type of bacterial cell wall: Its simple identification by calorimetric method. J. Gen Appl. Microbiol 23, 249-260 (1977).

35 Marmur, J. A procedure for the isolation of deoxyribonucleic acid from microorganisms. J. Mol. Biol. 3, 208-218 (1961).

36 Marmur, J. \& Doty, P. Determination of the base composition of deoxyribonucleic acid from its thermal denaturation temperature. J. Mol. Biol. 5, 109-118 (1962).

37 Chung Y. R. et al. Kitasatospora cheerisanensis sp. nov., a new species of the genus Kitasatospora that produces an antifungal agent. Int. J. Syst. Bacteriol. 49, 753-758 (1999)

38 Gonzalez, J. M. \& Saiz-Jimenez, C A. Simple fluorimetric method for the estimation of DNA-DNA relatedness between closely related microorganisms by thermal denaturation temperatures. Extremophiles 9, 75-79 (2005).

39 Larkin M. A. et al. Clustal W and Clustal X version 2.0. Bioinformatics 23, 2947-2948 (2007)

40 Kimura, M. A simple method for estimating evolutionary rates of base substitutions through comparative studies of nucleotide sequences. J. Mol. Evol. 16, 111-120 (1980).

$41 \mathrm{Kim}$ 0. S. et al. Introducing EzTaxon-e: a prokaryotic 16S rRNA Gene sequence database with phylotypes that represent uncultured species. Int. J. Syst. Evol. Microbiol. 62, 716-721 (2012)

42 Tamura, K., Stecher, G., Peterson, D., Filipski, A. \& Kumar, S. MEGA6: Molecula Evolutionary Genetics Analysis Version 6.0. Mol. Biol. Evol. 30, 2725-2729 (2013).

43 Saitou, N. \& Nei, M. The neighbor-joining method: a new method for reconstructing phylogenetic trees. Mol. Biol. Evol. 4, 406-425 (1987).

44 Kluge, A. G. \& Farris, F. S. Quantitative phyletics and the evolution of anurans. Syst. Zool. 18, 1-32 (1969).

45 Felsenstein, J. Evolutionary trees from DNA sequences: a maximum likelihood approach. J. Mol. Evol. 17, 368-376 (1981).

46 Felsenstein, J. Confidence limits on phylogenies: an approach using the bootstrap. Evolution 39, 783-791 (1985).

47 Wayne L. G. et al. International Committee on Systematic Bacteriology. Report of the ad hoc committee on reconciliation of approaches to bacterial systematics. Int. J. Syst. Bacteriol. 37, 463-464 (1987)

Supplementary Information accompanies the paper on The Journal of Antibiotics website (http://www.nature.com/ja) 